\title{
ANALYSING LANDSCAPE FRAGMENTATION AND CLASSIFYING THREATS FOR HABITATS OF COMMUNITY INTEREST IN THE “IRON GATES” NATURAL PARK (ROMANIA)
}

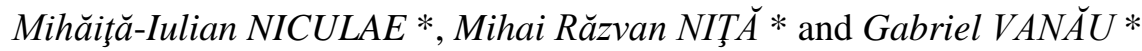 \\ * University of Bucharest, Centre for Environmental Research and Impact Studies, Nicolae Bălcescu \\ Boulevard 1, Sector 1, CP 010041, Bucharest, Romania, mihaitaiulian.niculae@g.unibuc.ro, \\ mihairazvan.nita@g.unibuc.ro, gabriel.vanau@geo.unibuc.ro
}

DOI: 10.1515/trser-2015-0042

KEYWORDS: Landscape fragmentation, landscape metrics, ecological impact, habitats of community interest, "Iron Gates” Natural Park, Romania.

\section{ABSTRACT}

Our study aims at evaluating the ecological impact of landscape fragmentation, identifying, and classifying the threats affecting habitats of community interest in the "Iron Gates” Natural Park. We used landscape metrics for assessing the fragmentation process, results expressing decreases in the values of three metrics (MPS, ED, SDI) and increases for two metrics (NumP and IJI). We observed an insignificant increase in landscape fragmentation related to a reduced decrease of its landscape diversity for the 1990-2006 timeframe. We classified the main anthropic threats to habitats of community interest in three main categories: diversification and densification of buildings and transportation infrastructures, land use and industrial activities.

RÉSUMÉ: Analyse de la fragmentation du paysage et classification des menaces pour les habitats d'intérêts communautaires dans le Parc Naturel des "Portes de Fer" (Roumanie).

L'étude réalise une évaluation de l'impact écologique des activités humaines sur les habitats et les espèces d'importance communautaire dans le Parc National "Portes de Fer". Une des conséquences majeurs de ces activités que nous avons analyse est la fragmentation de paysages, quantifie en utilisant les métriques paysagères. Les donnes obtenues montrent une baisse des valeurs pour trois indicateurs (MPS, ED, SDI) et une hausse des valeurs pour deux (NumP et IJI). Entre 1990-2006, la fragmentation du paysage a légèrement augmenté, entent que la diversité du paysage a diminué. Les formes de pression humaine sur les habitats ont été groupées en trois catégories: densification résidentielle et des voies de circulation, utilisation du terrain et activités industrielles.

REZUMAT: Analiza fragmentării peisajului și clasificarea ameninţărilor pentru habitatele de interes comunitar în Parcul Natural „Porţile de Fier”.

Studiul își propune să evalueze impactul ecologic indus de fragmentarea peisajelor asupra habitatelor și speciilor de importanță comunitară din Parcul Natural „Porțile de Fier”. Fragmentarea peisajului a fost cuantificată utilizând analiza metricilor peisajului. Rezultatele evidențiază scăderi ale valorilor în cazul a trei metrici (MPS, ED, SDI) și creșteri pentru doi metrici (NumP și IJI). La nivelul arealului s-a înregistrat o creștere nesemnificativă a fragmentării peisajului, coroborată cu o uşoară diminuare a diversităţii peisajului în intervalul 1990-2006. Formele de presiune umană au fost grupate în trei categorii: diversificarea și creşterea densităţii construcțiilor și a căilor de transport, modul de utilizare a terenurilor și activitățile industriale. 


\section{INTRODUCTION}

The establishment of the European network of protected areas - Natura 2000 - was an important step towards biodiversity conservation at European level (Evans, 2012; Primack et al., 2008). The network was established based on the legal provision of the core Directives of nature conservation: Habitats and Birds Directive (Pullin et al., 2009). The Directives have in their annexes a detailed list of European habitats that present a community interest, mainly due to their ecological characteristics.

A wide variety of studies focus on the habitats of community interest as part of the Natura 2000 network, but only a small proportion approach the social and political implications determining a reduced correspondence between the ecologic and social domains (Popescu et al., 2014). Ecological studies are more frequent, a furthermore proof of the fact that the enforcement of the Habitats and Birds Directives are focused on the conservation of habitats of community interest (Evans, 2012; Popescu et al., 2014).

Research on the conservation of biological diversity revealed that the main threats affecting protected areas networks are the degradation and destruction of habitats, overexploitation, invasive species, pollution or the inadequate spatial planning of the network (Ioja et al., 2010; Primack et al., 2008).

The human impact inside protected areas is amplified by changes in the land use, environmental degradation, the expansion of constructed surfaces and transportation infrastructures, the main effects being represented by the destruction and fragmentation of habitats (Fischer et al., 2007).

Current environmental threats induced by the new consumption models of population - densification of settlements, human induced landscapes and the diversification of economic activities (Antrop, 2004) should be evaluated as synergic process at local or global level (Chincea et al., 2014).

The social and economic vulnerability determined by the amplification of the human pressures imposes a system of sustainable management and territorial planning that consider the new environmental modifications, landscape characteristics and the need for resource consumption (Ioja, 2013; Lindenmayer et al., 2006).

The new directions of analysis should approach conflicts between conservation and development objectives at local, regional and global level (inside the protected areas from Natura 2000 network) (Popescu et al., 2014), with emphasis on the conflicts between agricultural practices and habitats (Pe'er et al., 2014) or the densification of built-up surfaces and the conservation of habitats and species of community interest.

Evaluations of the status of species and habitats inside a protected area can be realized using landscape metrics as an indicator of their dynamic under the influence of anthropic factors (dynamic of the fragmentation degree and landscape structure) (Niculae and Pătroescu, 2011; McGarigal and Marks, 1994; Turner and Meyer, 1994; McGarigal et al., 2002; PătruStupariu et al., 2011; Turner et al., 2001).

Landscape ecology represents a new direction in landscape research that focuses on the structure, composition, functions and the role of human communities in creating and modifying the landscape pattern (Farina, 1998; Forman, 1997; Burel and Baudry, 1999; Forman and Godron, 1986). 
In time, the intervention of human factors in the "Iron Gates" Natural Park manifested at different spatial scales and magnitudes, but had a significant role in the spatial and territorial dynamic of habitats of community interest. Species and habitats are differently affected by landscape fragmentation. In the study area among the factors found in the literature are the densifications of built-up surfaces, transportation infrastructures, landscape modification, etc.

The study assessed the ecological impacts induced on the habitats of community interest from the "Iron Gates" Natural Park by anthropic threats and subsequent landscape fragmentation. The research objectives are: a) to quantify landscape fragmentation for the 1990-2006 period using landscape metrics and evaluate its effects on habitats of community interest and b) to identify and classify the main categories of threats and prioritize the areas where they generate environmental conflicts in relation to habitats of community importance.

\section{MATERIAL AND METHODS \\ Study area}

The "Iron Gates" Natural Park is situated in the south-western part of Romania, on the border with Serbia, overlapping the territory of the Mehedinţi and Caraş-Severin counties (Pătroescu and Rozylowicz, 2000; Cucu et al., 2013a, b) and including 20 territorial administrative units. This park was established through Law 5/2000, Section III - Protected areas (Guvernul României, 2013) and is now included in the V category IUCN, managed especially for the conservation of terrestrial landscapes and recreation (IUCN, 2014).

Vegetation includes vascular plants with 1,749 species, 120 subspecies, 570 genus and 131 families (50\% of the number of species in Romania) (Matacă, 2005).

The "Iron Gates" Natural Park includes 18 reserves of avifauna, botanical, paleontological, forestry or mixed interest, established under legal provisions and presented in the management plan of the protected area: Balta Nera - Dunăre, Baziaş, Insula Calinovăţ, Râpa cu lăstuni, Divic-Pojejena, Valea Mare, Peştera cu apă din Valea Polevii, Ostrovul Moldova Veche, Locul fosilifer Sviniţa, Cazanele Mari and Cazanele Mici, Bahna, Dealul Duhovna, Gura Văii-Vârciorova, Fața Virului, Cracul Crucii, Dealul Vărănic, Valea Oglănicului, Cracul Găioara (Guvernul României, 2013; Pătroescu et al., 2004).

The "Iron Gates" Natural Park includes two Special Protection Areas, components of the Natura 2000 network: ROSPA0026 Cursul Dunării-Baziaş-Porţile de Fier and ROSPA0080 Munţii Almăjului-Locvei (Guvernul României, 2011). In 2007 the entire surface of the Park was designated as a Site of Community Importance (ROSCI0206 Porţile de Fier), included in the Natura 2000 network (Ministerul Mediului şi Pădurilor, 2011) (Fig. 1).

In the Site of Community Importance ROSCI0206 "Porţile de Fier"/“Iron Gates" 29 habitats of community interest have been identified according to Annex I of the Habitats Directive (Directiva 92/43/CEE), their conservation requiring the designation of special areas. From the 29 identified habitats (Tab. 1), seven are priority habitats for conservation (Ministerul Mediului şi Pădurilor, 2011).

In addition, a large number of species of community interest form Annex II of the Habitats Directive have been identified in the "Iron Gates" Natural Park, including 15 mammal species (of which one priority species - Canis lupus), four species of amphibians and reptiles, 12 fish species, 16 invertebrate species (of which two priority species, Osmoderma eremita and Rosalia alpina) and 12 species of plants (Ministerul Mediului şi Pădurilor, 2011). The two Special Protection Areas include species from Annex I of the Birds Directive: ROSPA0026 Cursul Dunării-Baziaş-Porţile de Fier - 13 species and ROSPA0080 Munţii Almăj - 21 species (Guvernul României, 2011). 
Table 1: Habitats of community interest in the "Iron Gates" Natural Park; *priority habitat types.

\begin{tabular}{|r|l|}
\hline 3130 & $\begin{array}{l}\text { Oligotrophic to mesotrophic standing waters with vegetation of the Littorelletea } \\
\text { uniflorae and/or of the Isoëto-Nanojuncetea }\end{array}$ \\
\hline 3140 & Hard oligo-mesotrophic waters with benthic vegetation of Chara ssp. \\
\hline 3150 & Natural eutrophic lakes with Magnopotamion or Hydrocharition - type vegetation \\
\hline 3260 & $\begin{array}{l}\text { Water courses of plain to montane levels with the Ranunculion fluitantis and } \\
\text { Callitricho-Batrachion vegetation }\end{array}$ \\
\hline \begin{tabular}{rl|} 
Constantly flowing Mediterranean rivers with Paspalo-Agrostidion species and \\
hanging curtains of Salix and Populus alba
\end{tabular} \\
\hline $6110^{*}$ & Subcontinental peri-Pannonic scrub \\
\hline 6190 & Rupicolous calcareous or basophilic grasslands of the Alysso-Sedion albi \\
\hline $6210^{*}$ & $\begin{array}{l}\text { Semi-natural dry grasslands and scrubland facies on calcareous substrates } \\
\text { (Festuco-Brometalia) } * \text { important orchid sites) }\end{array}$ \\
\hline $6260^{*}$ & Pannonic sand steppes \\
\hline 6430 & Hydrophilous tall herb fringe communities of plains and of the montane to alpine \\
\hline 8120 & $\begin{array}{l}\text { Calcareous and calcshist screes of the montane to alpine levels (Thlaspietea } \\
\text { rotundifolii) }\end{array}$ \\
\hline 8210 & Calcareous rocky slopes with chasmophytic vegetation \\
\hline 8220 & Siliceous rocky slopes with chasmophytic vegetation \\
\hline 8230 & $\begin{array}{l}\text { Siliceous rock with pioneer vegetation of the Sedo-Scleranthion or of the Sedo } \\
\text { albi-Veronicion dillenii }\end{array}$ \\
\hline 8310 & Caves not open to the public \\
\hline 9110 & Luzulo-Fagetum beech forests \\
\hline 9130 & Asperulo-Fagetum beech forests \\
\hline 9150 & Medio-European limestone beech forests of the Cephalanthero-Fagion \\
\hline 9170 & Galio-Carpinetum oak-hornbeam forests \\
\hline $9180^{*}$ & Tilio-Acerion forests of slopes, screes and ravines \\
\hline $91 \mathrm{AA} *$ & Eastern white oak woods \\
\hline $91 \mathrm{E} 0 *$ & $\begin{array}{l}\text { Alluvial forests with Alnus glutinosa and Fraxinus excelsior (Alno padion, Alnion } \\
\text { incanae, Salicion albae) }\end{array}$ \\
\hline $91 \mathrm{~K} 0$ & Illyrian Fagus sylvatica forests (Aremonio-Fagion) \\
\hline $91 \mathrm{~L} 0$ & Illyrian oak-hornbeam forests (Erythronio-Carpinion) \\
\hline $91 \mathrm{M} 0$ & Pannonian-Balkanic turkey oak - sessile oak forests \\
\hline $91 Y 0$ & Dacian oak and hornbeam forests \\
\hline $92 \mathrm{~A} 0$ & Salix alba and Populus alba galleries \\
\hline $9530 *$ & (Sub-) Mediterranean pine forests with endemic black pines \\
\hline
\end{tabular}

\section{Landscape fragmentation}

For quantifying and analysing landscape fragmentation we used the spatial database established by the EEA in the CORINE Land Cover Project for the years 1990 and 2006 (Bossard et al., 2000; Feranec et al., 2010; Heymann et al., 1994), in a grid format with a resolution of $100 * 100$ meters, which we projected in the Stereo 1970 system. 


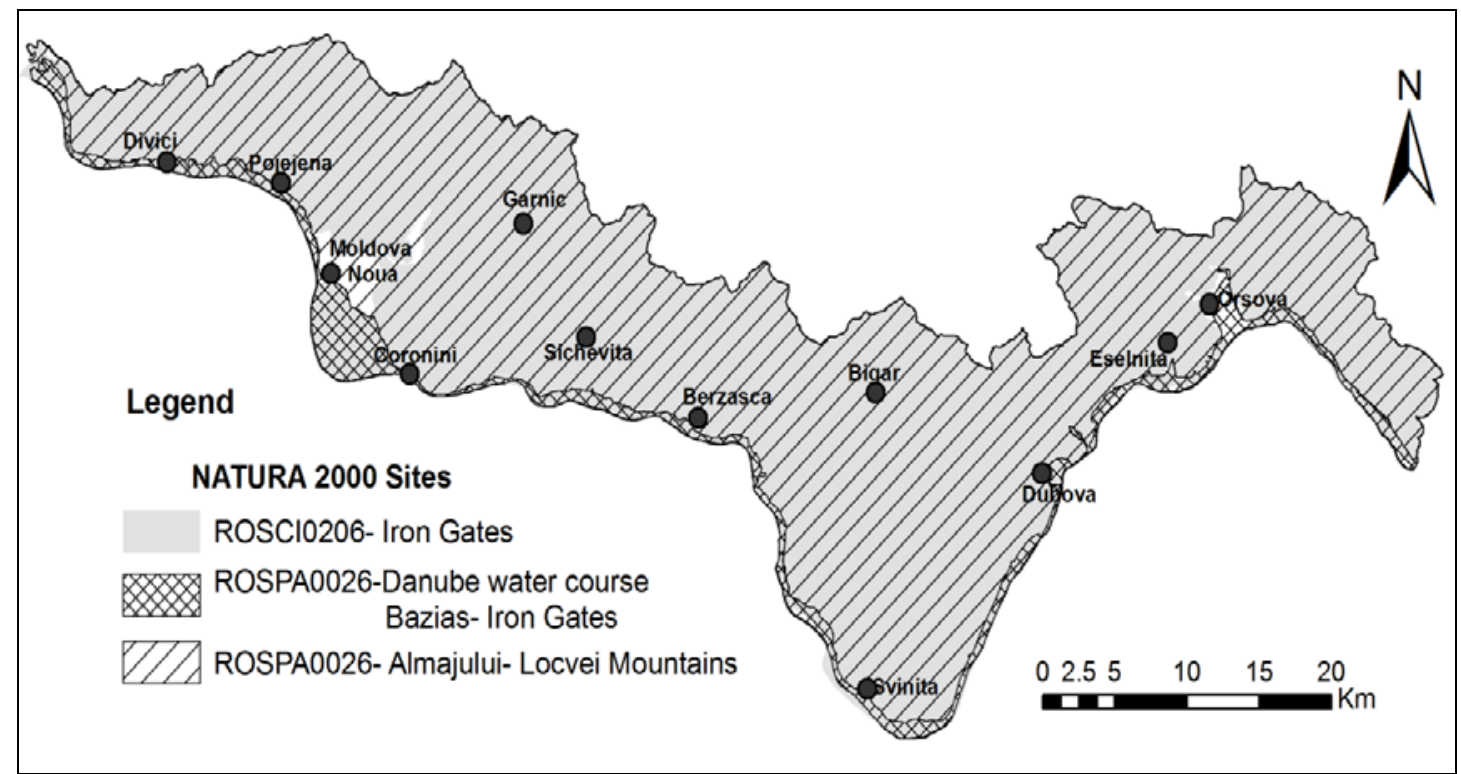

Figure 1: Natura 2000 sites in the "Iron Gates” Natural Park.

The interval corresponds to the Romanian post-communist period characterized by a transition economy. We aggregated land use and land cover classes extracted from the CORINE database (19 classes) in nine main classes (Tab. 2) according to the CLC nomenclature system level II (Eiden et al., 2000) accounting for the particularities of the protected area and the objectives of our study.

Regarding the evaluation of the landscape pattern and the fragmentation of habitats we used five landscape metrics (Eiden et al., 2000; Niculae, 2012), based on the number, size, diversity and the overlap of units in the landscape pattern (Tab. 3).

We calculated landscape metrics using the software Patch Analyst 5.0 (Rempel et al., 2012) and its function Spatial Statistics, developed by the Centre for Northern Forest Ecosystem Research, Lakehead University, Ontario.

\section{Threats analysis}

The identification and classification of anthropic threats upon habitats of community interests, and the prioritization of areas with environmental conflicts was done based on the observations and field collection of data, as well as interviews with local actors from the protected area (Cucu et al., 2013a; Primack et al., 2008).

In addition, we consulted a large body of literature (articles, proceedings, reports, management plans) on the topic of environmental conflicts determined by human activities on habitats and species. We validated the data with information from aerial images and cartographic materials.

For prioritizing threats, we used diverse criteria such as the number of landscape components influenced by human activities, environmental impact assessment for different land uses and the proximity to habitats of community interest. Land uses have a spatial and temporal evolution determined by the local and regional development, densification of built-up surfaces and the need to increase the accessibility of the protected area (CCMESI, 2014). 
The identification and prioritization of areas with environmental conflicts was realized according to the relation between the densification of built-up and industrial surfaces and habitats of community interest from the "Iron Gates" Natural Park.

Table 2: Classes obtained from reclassification.

\begin{tabular}{|c|c|c|c|}
\hline $\begin{array}{c}\text { Name of CLC classes } \\
\text { (level 2) }\end{array}$ & $\begin{array}{c}\text { CLC Code level } 2 \\
\text { (level 3) }\end{array}$ & $\begin{array}{c}\text { Name of reclassified } \\
\text { classes }\end{array}$ & Code \\
\hline Built-up surfaces & $11(112)$ & \multirow{3}{*}{ Artificial surfaces } & \multirow{3}{*}{1} \\
\hline $\begin{array}{l}\text { Industrial and commercial } \\
\text { units }\end{array}$ & $12(121 ; 123)$ & & \\
\hline $\begin{array}{l}\text { Mines, dumps and sites for } \\
\text { construction materials }\end{array}$ & $13(131 ; 132)$ & & \\
\hline Agricultural fields & 21 (211) & Arable lands & 2 \\
\hline Permanent crops & $22(221 ; 222)$ & Permanent crops & 3 \\
\hline Pastures & $23(231)$ & Pastures & 4 \\
\hline $\begin{array}{l}\text { Heterogeneous agricultural } \\
\text { fields }\end{array}$ & $2.4(242 ; 243)$ & $\begin{array}{c}\text { Heterogeneous } \\
\text { agricultural fields }\end{array}$ & 5 \\
\hline Forests & $31(311 ; 313)$ & Forests & 6 \\
\hline $\begin{array}{c}\text { Shrubs and/or grass } \\
\text { vegetation }\end{array}$ & $32(321 ; 324)$ & Natural vegetation & 7 \\
\hline Reduced or no vegetation & 33 (332; 333) & Unproductive lands & 8 \\
\hline Water bodies & $51(511 ; 512)$ & Water bodies & 9 \\
\hline
\end{tabular}

Table 3: Landscape metrics used in the analysis (McGarigal and Marks, 1994).

\begin{tabular}{|c|c|c|}
\hline Indicator & Formula*/Description & $\begin{array}{l}\text { Measure/ } \\
\text { Values }\end{array}$ \\
\hline $\begin{array}{l}\text { Number of } \\
\text { patches } \\
\text { (NumP) }\end{array}$ & $\begin{array}{l}\qquad N P=n \\
\text { The value is } 1 \text { when the entire landscape has a single patch. } \\
\mathrm{n}=\text { total number of landscape patches, without background } \\
\text { units }\end{array}$ & $\begin{array}{c}\text { NumP } \geq 1 \\
\text { no limits }\end{array}$ \\
\hline $\begin{array}{l}\text { Mean patch } \\
\text { size (MPS) }\end{array}$ & $\begin{array}{l}\qquad M P S=\frac{A}{N}\left(\frac{1}{10,000}\right) \\
\text { Values range by the limits of the resolution, scales and the } \\
\text { minimum size of the unit. Final value can be divided by } \\
10,000 \text { to convert in ha. } \\
A=\text { total landscape surface }\left(\mathrm{m}^{2}\right) ; \mathrm{N}=\text { total number of patches }\end{array}$ & $\begin{array}{l}\text { ha } \\
\text { MPS }>0 \text {, } \\
\text { no limits }\end{array}$ \\
\hline $\begin{array}{l}\text { Edge density } \\
\text { (ED) }\end{array}$ & $\begin{array}{l}\qquad E D=\frac{E}{A}(10,000) \\
\text { Sum of lengths for all edge segments in the landscape in } \\
\text { relation to the total surface. Final value can be divided by } \\
10,000 \text { to convert in ha. } E \text { = total lenght (m) of edge } \\
\text { segments; can include the landscape limit; } A=\text { total surface } \\
\text { of the landscape }\left(\mathrm{m}^{2}\right)\end{array}$ & $\begin{array}{c}\mathrm{m} / \mathrm{ha} \\
\mathrm{ED} \geq 0 \\
\text { no limits }\end{array}$ \\
\hline
\end{tabular}


Table 3 (continued): Landscape metrics used in the analysis.

\begin{tabular}{|c|c|c|}
\hline Indicator & Formula*/Description & $\begin{array}{c}\text { Measure/ } \\
\text { Values }\end{array}$ \\
\hline $\begin{array}{c}\text { Shannon } \\
\text { diversity index } \\
\text { (SHDI) }\end{array}$ & $\begin{array}{l}\qquad S H D I=-\sum_{i=1}^{m}(P i \circ \ln P i) \\
\text { The value equals } 0 \text { when the landscape contains a single unit } \\
\text { (no diversity) and increases with the number of classes } \\
\text { and/or the balanced distribution between surfaces. The value } \\
\text { is equal to minus the sum of the proportional abundance for } \\
\text { each type of patch and their proportion. } \mathrm{M}=\text { number of } \\
\text { patches for the } i \text { class with close neighbours; } \mathrm{i}=1, \ldots, \mathrm{m} \text {, } \\
\text { types of landscape classes; } \mathrm{p}_{\mathrm{i}}=\text { perimeter }(\mathrm{m}) \text { of unit } i\end{array}$ & $\mathrm{SHDI} \geq 0$ \\
\hline $\begin{array}{l}\text { Interspersion } \\
\text { and } \\
\text { juxtaposition } \\
\text { index (IJI) }\end{array}$ & $\begin{array}{l}\qquad I J I=\frac{-\sum_{i=1}^{m^{\prime}} \sum_{k=i+1}^{m^{\prime}}\left[\left(\frac{e_{i k}}{E}\right) \cdot \ln \left(\frac{e_{i k}}{E}\right)\right]}{\ln \left(1 / 2\left[m^{\prime}\left(m^{\prime}-1\right)\right]\right)} \\
\text { The index equals } 0 \text { when the distribution of adjacent classes } \\
\text { between unique classes increases unbalance and equals } 100 \\
\text { when all classes are equally adjacent to the other classes. } \\
m \text { ' = number of class types present in the landscape without } \\
\text { the limit; } \mathrm{i}=1, \ldots, \mathrm{m}, \text { class types; } \mathrm{k}=1, \ldots, \mathrm{m} \text {, landscape } \\
\text { class types; } \mathrm{e}_{\mathrm{ik}}=\text { total length (m) of landscape edges between } \\
i \text { and } k \text { units; } \mathrm{E}=\text { total length }(\mathrm{m}) \text { of landscape edges } \\
\text { (including landscape limit) }\end{array}$ & $\begin{array}{c}\% \\
0<\mathrm{IJI} \leq 100\end{array}$ \\
\hline
\end{tabular}

\section{RESULTS AND DISCUSSION}

The analysis of landscape fragmentation and landscape pattern revealed decreases for three landscape metrics (MPS, ED, SDI) and increases for the other two (NumP and IJI) (Tab. 4). The number of patches (NumP) recorded insignificant increases, with approximately $1.8 \%$ for the analysed timeframe, from 428 units in 1990 to 436 units in 2006. The values demonstrate a small increase in landscape fragmentation. Edge density (ED) decreased with $1.24 \%$, reaching a value of 20.67 in 2006, while the mean patch size (MPS) decreased with $1.84 \%$, arguments for landscape fragmentation and an increased complexity of shapes.

Table 4: Landscape metrics values for 1990 and 2006; *NumP-Number of patches; ED - Edge density; MPS - Mean patch size; SHDI - Shannon diversity index; IJI - Interspersion and juxtaposition index.

\begin{tabular}{|c|c|c|c|c|c|}
\hline & NUMP* & ED & MPS & SHDI & IJI \\
\hline 1990 & 428.00 & 20.93 & 299.53 & 1.24 & 63.19 \\
\hline 2006 & 436.00 & 20.67 & 294.03 & 1.23 & 65.33 \\
\hline
\end{tabular}

The Shannon Diversity Index (SDI) presents a small decrease of $0.81 \%$, from 1.24 to 1.23 in 2006. The index is used for quantifying landscape diversity (Pătru-Stupariu et al., 2009; Pătru-Stupariu et al., 2011; Schreiber et al., 2003) based on the composition (number of classes) and structure (distributions and proportions covered in the landscape) (Eiden et al., 2000; Niculae, 2012; Schreiber et al., 2003). 
The value of the index increases as the number of land use classes amplifies and their distribution in the landscape balances (Schreiber et al., 2003). In the case of the "Iron Gates" Natural Park, the insignificant decreases in the Shannon Diversity Index (from 1.24 to 1.23) would imply a reduced diversity of the landscape. However, since the number of classes remained constant for the analysed timeframe this reduction can be justified by a decrease in the proportion of several land uses and covers.

Values of the Interspersion and Juxtaposition Index (IJI) increased by approximately $3.4 \%$ in 2006 compared to 1990 (2.14 units). The high values for both years indicated an increased adjacency between landscape units from the same class in relation to the others, their distribution becoming regular in a progressive manner.

The five landscape metrics we analyzed for the years 1990 and 2006 reveal an insignificant increase of landscape fragmentation and a reduced decrease of landscape diversity. One of the reasons that generated these results was the establishment of the protected area status in 2005; land use and land cover changes recording a low manifestation in the protected area. Landscape fragmentation was determined also by the densification of built-up surfaces in settlements from the "Iron Gates" Natural Park.

Works on the European road E70 lead to the fragmentation of forest landscapes, affecting the structure of habitats consisting of calcareous and siliceous rocky slopes with chasmophytic vegetation. Constructions along the Danube banks (Fig. 2) destructed the habitats of alluvial forests with Alnus glutinosa and Fraxinus excelsior.

An important habitat for orchids, semi-natural dry grasslands and scrubland facies on calcareous substrates (Festuco-Brometalia) was affected by the fragmentation for obtaining agricultural lands in the proximity of settlements as Berzasca or Dubova.

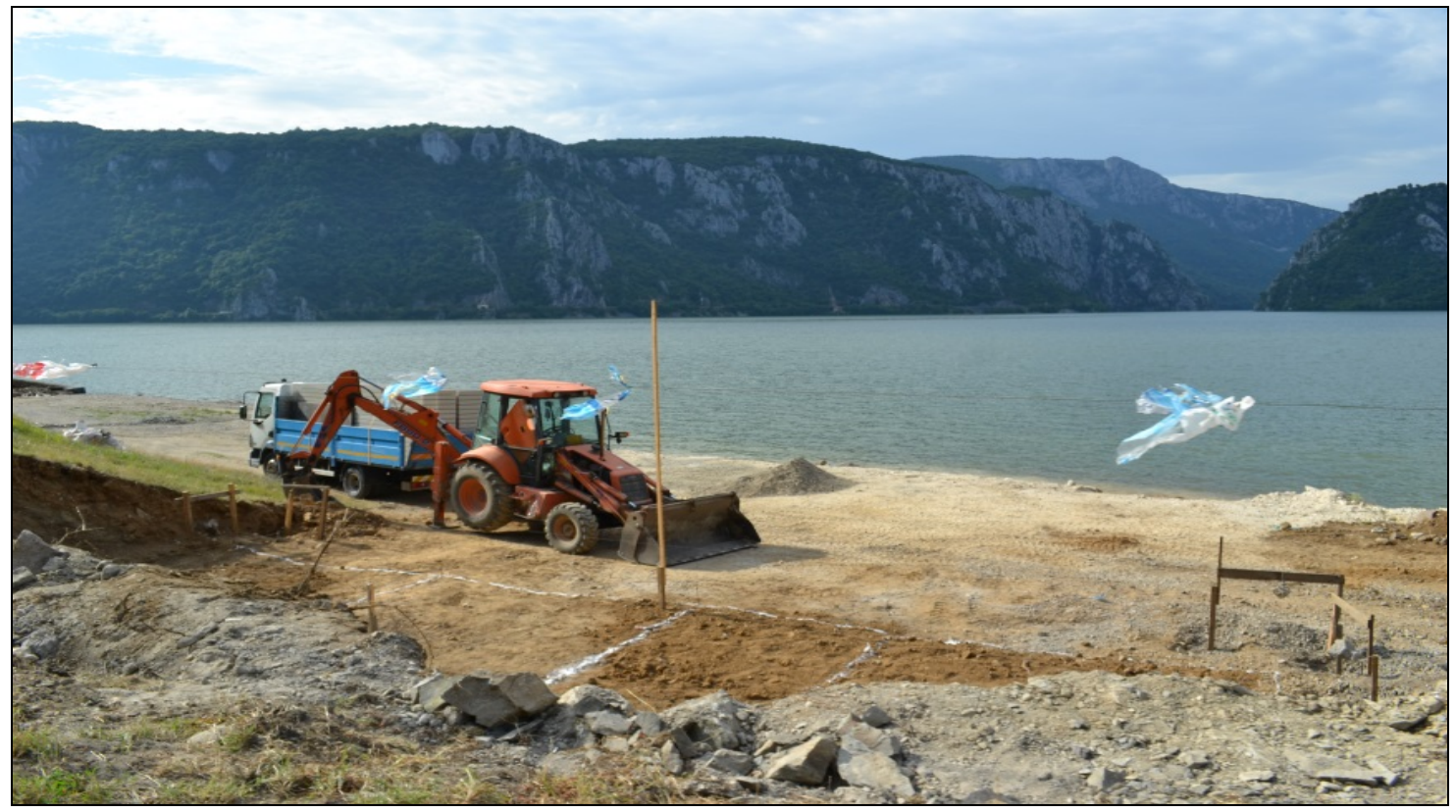

Figure 2: Constructions along the Danube banks at Dubova. 
Based on field researches and literature reviews we identified and classified a series of anthropic threats to landscapes in the "Iron Gates" Natural Park, with major negative effects on the habitats of community interest.

We also prioritized the areas in which a series of environmental conflicts can be found.

Human activities that determine pressure on the habitats of community interest belong to three categories: densification of human settlements (the number and density of permanent and temporary settlements, their shape and size), densification of transportation infrastructure (at national, county and local level) and land-uses (agricultural lands, animal growth, forestry, industrial activities) (CCMESI, 1999; CCMESI, 2014; Niculae, 2012). We prioritized the following human activities that influence habitats of community interest (CCMESI, 2014):

- Densification of built-up and commercial surfaces. The main threat is represented by the construction of vacation housings along the Danube, with direct effects on the ripicol and riparian habitats, as well as protected species (such as Testudo hermanni). The new insertions represent direct threats through the destruction of habitats (CCMESI, 2014);

- Transport activities on the roads and the Danube, especially along the E70 affecting habitats (Fig. 3) with rupicolous calcareous or basophilic grasslands of the Alysso-Sedion albi;

- Intensification of agricultural activities, especially in the area of depression basins or mountainous plateaus, affecting habitats with rupicolous calcareous or basophilic grasslands of the Alysso-Sedion albi or the semi-natural dry grasslands and scrubland facies on calcareous substrates (Festuco-Brometalia);

- Mining and energy production (at Cozla, Eibenthal, Baia Nouă) with direct impact especially on forest landscapes (Fig. 4). A threat is represented by the tailing dumps situated in the proximity of habitats. The existence of the "Iron Gates" hydro energy system has effects on the habitats, mainly through water level oscillation. Lately numerous wind turbines have been builded in the study area with direct effects especially on bird species and their habitats.

Settlements have an unbalanced distribution in the "Iron Gates" Natural Park, with higher densities along river valleys and the main roads, and in areas where slopes and fragmentation are reduced. Relief factors of restrictiveness determined a reduced density of population in the Caraș-Severin and Mehedinți counties.

A large proportion of the constructed surfaces and industrial activities are located in the proximity of protected areas and habitats of community interest (Fig. 5) increasing the probability of environmental conflicts emerging.

Numerous conflict areas from the "Iron Gates” Natural Park are concentrated around industry, many of them being residual activities from the communist period. The exploitation of different resources determined a high impact on environment, respectively on habitats and species of community interest. Conflict areas can be found around exploitation quarries, tailing dumps, mines or abandoned constructions (Moldova Noua, Cozla, Baia Nouă, etc.).

The city of Moldova Nouă is confronted with the largest number of conflict areas due to industrial activities (Chincea et al., 2014). The main conflict area induced by industrial activities is located at the tailing dump of Moldova Nouă, situated near the Ostrovul Moldova Veche wetland (Fig. 6) - part of ROSPA0026 Cursul Dunării - Baziaş-Porţile de Fier. It has a surface of about 270 ha and represents a cross-border environmental degradation sources.

These environmental conflicts are generated by the densification of built-up surfaces in the adjacent settlements and agricultural land uses. Such areas are found around the settlements of Eșelnița, Dubova, and Berzasca, in which the construction of vacation residences and their endowments determined the emergence of new environmental conflicts. 


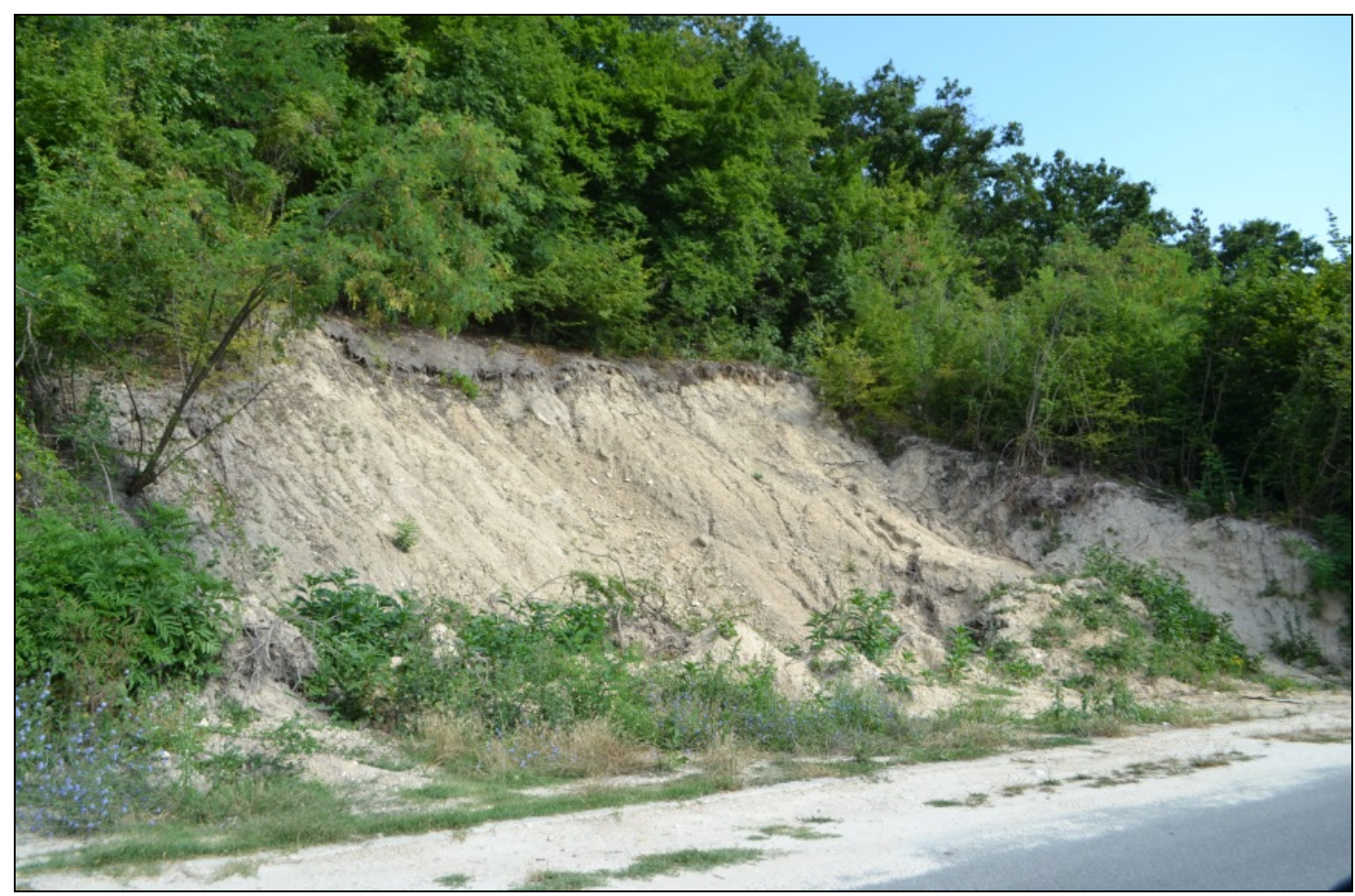

Figure 3: Landscape fragmentation by E70.

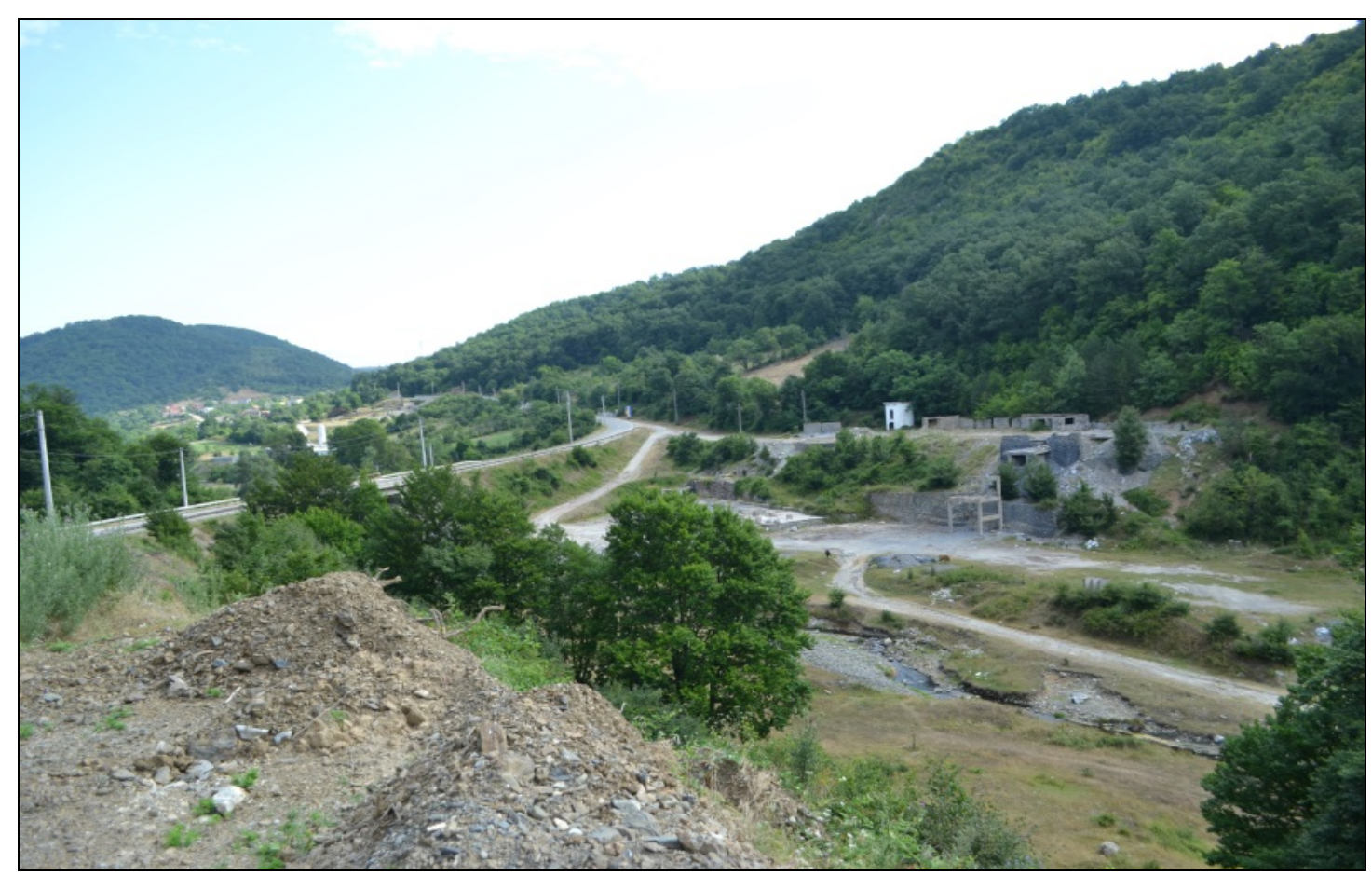

Figure 4: Mining exploitation in the proximity of Ciucarul Mare. 


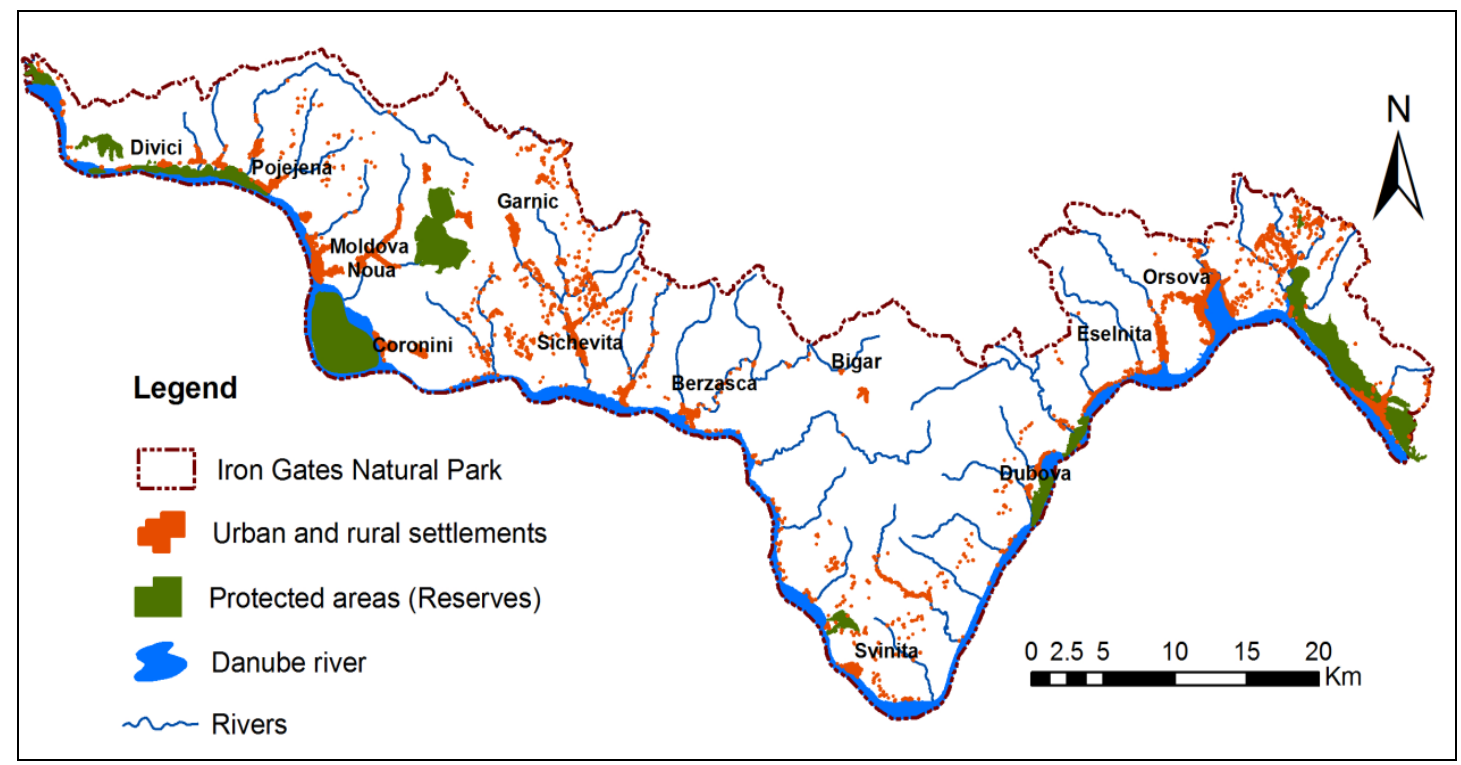

Figure 5: Densification of built-up surfaces in relation with reserves in the "Iron Gates" Park.

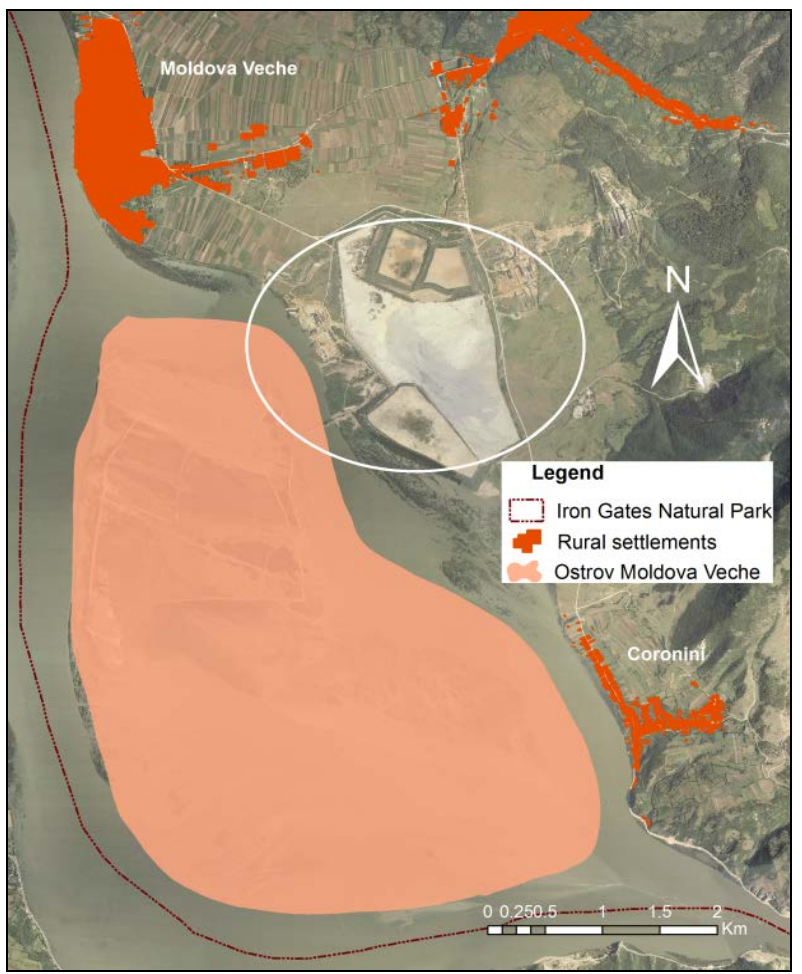

Figure 6: Conflict area determined by the presence of the tailing dump in the proximity of the Ostrovul Moldova Veche wetland.

Another area in which environmental conflicts are manifesting is represented by the area of the Calinovăț Island and the Divici - Pojejena wetlands (Figs. 7 and 8). 


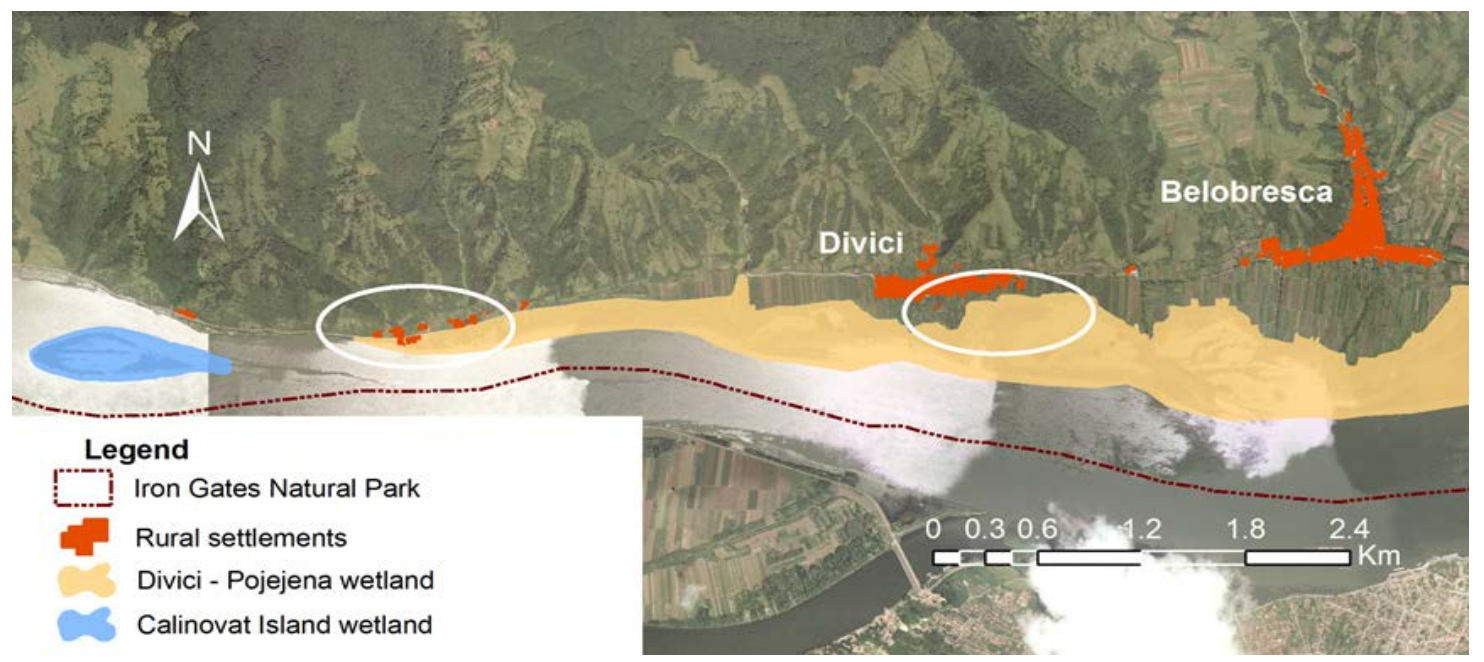

Figure 7: Conflicts generated by the densification of built-up surfaces.

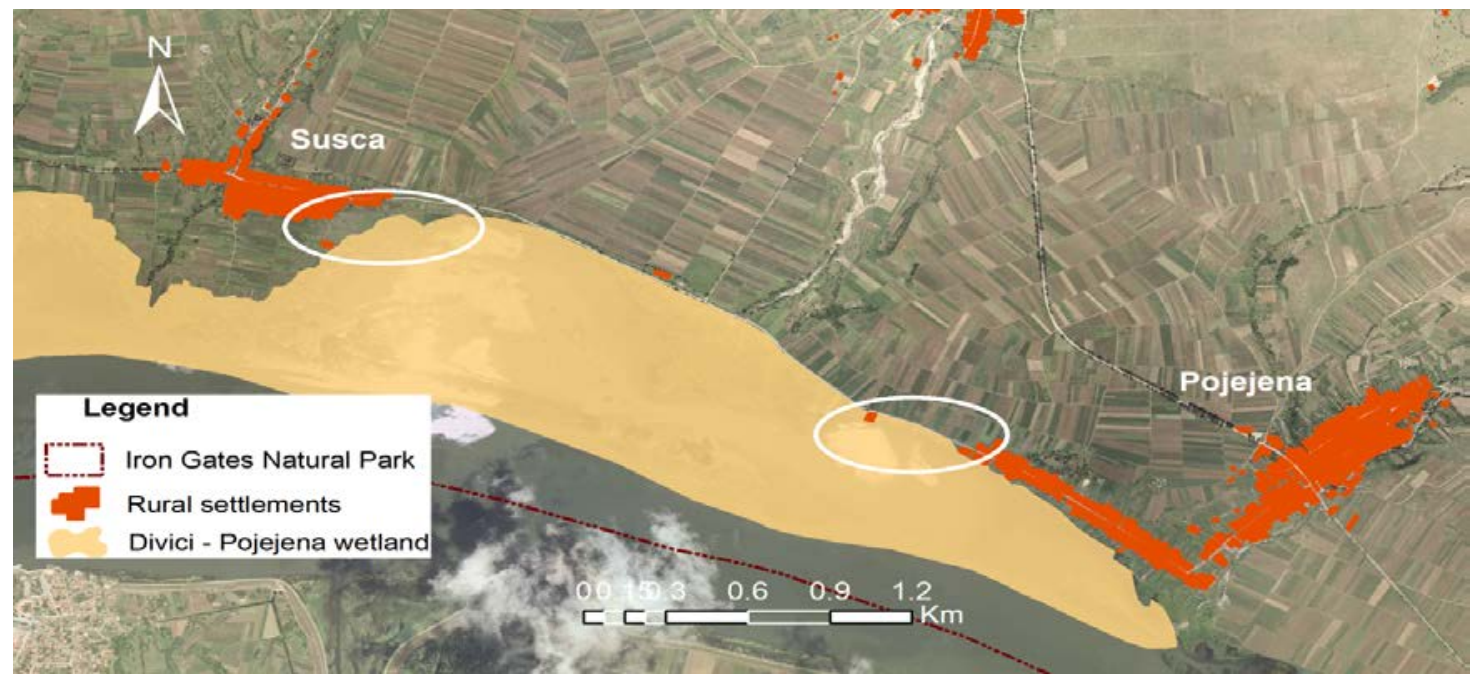

Figure 8: Densification of built-up surfaces and intensification of agriculture.

\section{CONCLUSIONS}

The "Iron Gates" Natural Park represents an area in which landscapes have suffered reduced modifications after its establishment as a protected area (2000) in comparison with territories in the proximity that lack a conservation status (CCMESI, 2014). The ecological integrity of the environment in the "Iron Gates" Natural Park was in a low proportion influenced by landscape fragmentation.

Recent changes in the structure of landscapes have not yet induced significant changes in spatial relations established in time between landscape elements. The connectivity and permeability of habitats is of significant importance in the framework of a protected area where the development of human activities (transportation, energy, agriculture) tends to determine fragmentation and represent barriers in the dispersion of species.

\section{ACKNOWLEDGEMENTS}

We acknowledge the support of our colleagues from the CCMESI - Bucharest University. 


\section{REFERENCES}

1. Antrop M., 2004 - Landscape change and the urbanization process in Europe, Landscape and Urban Planning, 67, 9-26.

2. Bossard M., Feranec J. and Otahel J., 2000 - Technical report no. 40. CORINE land cover technical guide - Addendum 2000, European Environment Agency, Copenhagen, 105.

3. Burel F. and Baudry J., 1999 - Ecologie du paysage, Editions TEC and DOC, Paris, 359. (in French)

4. CCMESI, 1999 - Dinamica peisajelor rurale din România, Studiu de caz: Câmpia Română, Contract 17/1998, Cod CNCSU 56A, Tema 2, Bucureşti. (in Romanian)

5. CCMESI, 2014 - Integrated Management Of Biological And Landscape Diversity For Sustainable Regional Development And Ecological Connectivity In The Carpathians.

6. Chincea I., Niculae M. I., Pătroescu M. and Nita M. R., 2014 - Spatial-temporal forms of Human pressure and their environmental impacts in the Caraş-Severin County, Romania, World Journal of Environmental Research, 4, 2, 53-60.

7. Cucu L. A., Niculae M. I. and Pătroescu M., 2013a - Hierarchical analysis of the threats for species of Community Interest in the "Iron Gates" Natural Park, Romania, Forum Geografic, Studii și cercetări de geografie și protecția mediului, 12, 1, 52-58.

8. Cucu L. A., Niculae M. I. and Pătroescu M., 2013b - Species management in the "Iron Gates" Natural Park, Present Environment and Sustainable Development, 7, 2, 145-155.

9. $\quad$ Eiden G., Kayadjanian M. and Vidal C., 2000 - Quantifing Landscape Structures: spatial and temporal dimensions, in From land cover to landscape diversity in the European Union, EU, http://ec.europa.eu/agriculture/publi/landscape/ch2.htm\#2, Accessed at 27.04.2015.

10. Evans D., 2012 - Building the EU's Natura 2000 network, Nature Conservation, 1, 11-26.

11. Farina A., 1998 - Principles and methods in landscape ecology, Chapman and Hall, London, 412.

12. Feranec J., Jaffrain G., Soukup T. and Hazeu G., 2010 - Determining changes and flows in European landscapes 1990-2000 using CORINE land cover data, Applied Geography, 30, 19-35.

13. Fischer J. and Lindenmayer D. B., 2007 - Landscape modification and habitat fragmentation. A synthesis, Global Ecology and Biogeography, 16, 265-280.

14. Forman R. T. T., 1995 - Land mosaics: the ecology of Landscapes and Regions, Cambridge University Press, Cambridge, 656.

15. Forman R. T. T. and Gordon M., 1986 - Landscape Ecology, John Wiley and Sons, New York, 618.

16. Guvernul României, 2011 - HG nr. 971/2011 pentru modificarea şi completarea Hotărârii Guvernului nr. 1.284/2007, Monitorul Oficial al României, I, 715/2011. (in Romanian)

17. Guvernul României, 2013 - Hotărârea nr. 1048/2013, Monitorul Oficial al României, I, 119/2014. (in Romanian)

18. Heymann Y., Steenmans C., Croisille G. and Bossard M., 1994 - CORINE Land Cover. Technical guide, Office for Official Publication of the EC, Luxembourg, 136.

19. Ioja C., Pătroescu M., Rozylowicz L., Popescu V., Vergheleț M., Zotta M. and Felciuc M., 2010 - The efficacy of Romania's protected areas, Biological Conservation, 143, 11, 2468-2476.

20. Ioja C., 2013 - Metode de evaluare a stării mediului, Edit. Etnologică, Bucureşti, 183. (in Romanian)

21. IUCN, 2014 - IUCN Protected Areas Categories System, available at http://www.iucn.org/about/work/programmes/gpap_home/gpap_quality/gpap_pacategories.

22. Lindenmayer D. B. and Fischer J., 2006 - Habitat fragmentation and landscape change, An ecological and conservation synthesis, Island Press, Washington, DC, 88-106.

23. Matacă S. S., 2005 - Parcul Natural Porțile de Fier. Floră, Edit. Universitaria, Craiova. (in Romanian)

24. McGarigal K. and Marks B. J., 1994 - FRAGSTATS, Spatial pattern analysis program for quantifying landscape structure, Version 2.0, Oregon State University, Corvallis, OR, 134. 
25. McGarigal K., Cushman S. A., Neel M. C. and Ene E., 2002 - FRAGSTATS: Spatial Pattern Analysis Program for Categorical Maps, Amherst, MA, University of Massachusetts, available at http://www.umass.edu/landeco/research/fragstats/fragstats.html, accessed at 22.04.2015.

26. Ministerul Mediului și Pădurilor, 2011 - Ordinul nr. 2387/2011 pentru modificarea Ordinului ministrului mediului şi dezvoltării durabile nr. 1.964/2007 privind instituirea regimului de arie naturală protejată a siturilor de importanţă comunitară, ca parte integrantă a reţelei ecologice europene Natura 2000, Monitorul Oficial al României, I, 846/2011. (in Romanian)

27. Niculae M. I. and Pătroescu M., 2011 - Quantifying forest ecosystems fragmentation in the Subcarpathians between the Râmnicu Sărat and the Buzău valleys, Romania, using landscape metrics, Forum Geografic, Studii şi cercetări de geografie şi protecţia mediului, 10, 1, 187-194.

28. Niculae M. A. I., 2012 - Evoluţia spaţială şi temporală a peisajelor din Subcarpaţii cuprinşi între Buzău şi Râmnicu Sărat, Edit. Universităţii din Bucureşti, Bucureşti. (in Romanian)

29. Pătroescu M. and Rozylowicz L., 2000 - Natural Transborder Parks: the direction of Biodiversity preservation in Romania, in Crabbe P. et al. (ed.) Implementing ecological integrity, Kluwer Academic Press, 101-113.

30. Pătroescu M., Chincea I., Pascovici N., Ioja C., Matacă S. S., Popa M. E., Florescu V., Vâlceanu C., Odorescu I., Popescu V., Dumitraşcu D., Rozylowicz L., Necsuliu R. and Sbîrcea S., 2004 Planul de management al Parcului Natural Porțile de Fier în perspectiva dezvoltării durabile, Drobeta, Seria Științele naturii, XIV, Edit. Craiova, Drobeta Turnu-Severin, 64-92. (in Romanian)

31. Pătru-Stupariu I., Stupariu M. S. and Cuculici R., 2009 - Landscape metrics for assessment of mountain landscape using GIS applications, Revista de Geomorfologie, 11, 59-62.

32. Pătru-Stupariu I., Stupariu M. S., Cuculici R. and Huzui A., 2011 - Application of the global indicators to landscape change modeling on Prahova Valley (Romanian Carpathians and Subcarpathians), International Journal of the Physical Sciences, 6, 3, 534-539.

33. Pe’er G., Dicks L. V., Visconti P., Arlettaz R., Báldi A., Benton T. G., Collins S., Dietrich M., Gregory R. D., Hartig F., Henle K., Hobson P. R., Kleijn D., Neumann R. K., Robijns T., Schmidt J., Shwartz A., Sutherland W. J., Turbé A., Wulf F. and Scott A. V., 2014 - EU agricultural reform fails on biodiversity, Science, 344, 1090-1092.

34. Popescu V. D., Rozylowicz L., Niculae I. M., Cucu A. L. and Hartel T., 2014 - Species, Habitats, Society: An Evaluation of Research Supporting EU's Natura 2000 Network, PLoS ONE, 9, 11, e113648.

35. Primack R. B., Pătroescu M., Rozylowicz L. and Ioja C., 2008 - Fundamentele conservării diversităţii biologice, Edit. AGIR, Bucureşti, 668 (in Romanian)

36. Pullin A. S., Baldi A., Can O. E., Dieterich M., Kati V., Livoreil B., Lövei G., Mihók B., Nevin O., Selva N. and Sousa-Pinto I., 2009 - Conservation Focus on Europe: Major Conservation Policy Issues, Conservation Biology, 23, 818-824.

37. Rempel R. S., Kaukinen D. and Carr A. P., 2012 - Patch Analyst and Patch Grid, Ontario Ministry of Natural Resources, Centre for Northern Forest Ecosystem Research, Thunder Bay, Ontario. Available at http://www.cnfer.on.ca/SEP/patchanalyst/, accessed at 26.04.2015.

38. Rozylowicz L., 2008 - Metode de analiză a distribuţiei areal-geografice a ţestoasei lui Hermann (Testudo hermanni Gmelin, 1789) în România, Studiu de caz: Parcul Natural Porţile de Fier, Edit. Universităţii din București. (in Romanian)

39. Schreiber W. E., Drăguţ L. and Man T. C. (eds), 2003 - Analiza peisajelor geografice din partea de vest a Câmpiei Transilvaniei, Presa Universitară Clujeană, Cluj-Napoca. (in Romanian)

40. Turner I. B. L. and Meyer W. B., 1994 - Global Land-Use and Land Cover Change: An Overview, in Changes in Land Use and Land Cover: A global Perspective, Mezer B. I. and Turner B. L., (eds), Cambridge University Press.

41. Turner M. G., Gardner R. H. and O’Neill R. V., 2001 - Landscape ecology in theory and practice, Pattern and process, Springer-Verlag, New York, USA, 406. 